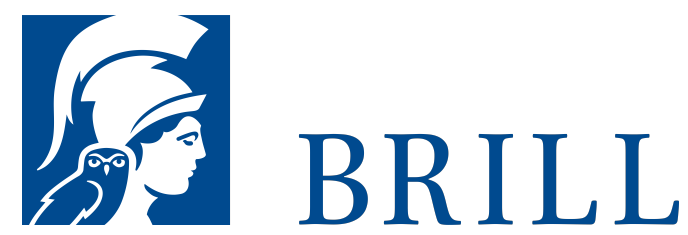

\title{
Die theopolitische Stunde
}

Zwölf Perspektiven auf das eschatologische Problem der Moderne

Author: Christoph Schmidt

Die theopolitische Stunde benennt die radikale Krise der Kulturidee und spezifisch der deutsch-jüdischenKultur in den Jahren zwischen 1910 und 1938, wie sie in durchaus verschiedenen Formen politischer Theologie - von Leo Strauss, Martin Buber, Ger-schom Sholem bis Jacob Taubes - reflektiert wird. Allen Texten eingeschrieben ist die für die Kulturkrise symptomatische Erfah-rung, dass die ethische Kulturidee als „Freiheit unter dem Gesetz“ mit der fundamental gesetz- und normtrans-zendierenden Individualität in Konflikt geraten muss. Dabei wird dieser Kon-flikt zunächst vor allem auf der ästheti-schen Ebene (Simmel) artikuliert, die allerdings immer schon mit der theo-logischen Dimension des Konflikts kommuniziert. Im jüdischen Kontext entspricht diese Situation der Erfah-rung, dass die Kulturidee zwar die Emanzipation des Juden ermöglicht hat, allerdings nur unter der Bedin-gung einer Emanzipation von seinem Judentum.

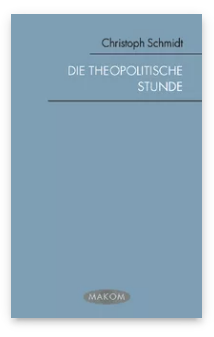

Pages: 321

Seiten

Language:

German

Subjects:

General,

Philosophy

Publisher: Brill |

Fink

Series:

Makom, Volume:

6

E-Book (PDF)

Released online: o1 Oct 2019

ISBN: $978-3^{-}$

8467-4371-3

List price

USD $\$ 63.00$

Paperback

Publication date: 18 Mar 2009

ISBN: 978-3-

7705-4371-7

List price

USD \$63.00 
For more information see brill.com

Order information: Order online at brill.com +44330 333 0049 | customerservices@brill.com Submission information: brill.com/authors

Titles published by Brill | Fink, Brill | mentis or Brill | Schöningh: +49(o)715413279216| brill@brocom.de 